\title{
TOWARDS A DEFINITION OF CONTROLLING
}

\author{
Mihaela Mocanu \\ Bucharest University of Economic Studies, Romania \\ mihaela.mocanu@cig.ase.ro
}

\begin{abstract}
Controlling is a concept that is still subject of many controversies. Nowadays, it is used both in theory and in practice to designate a variety of activities. The paper aims at shedding light on this enigmatic concept. First of all, the author offers an overview of the historical roots of "controlling". Secondly, different definitions of the concept of "controlling" are contrasted. The author comments upon two types of definitions: concepts oriented towards the goal to obtain results (profit, turnover, low costs) and concepts oriented towards the universal goals of the company (e.g. product-related, environmental, social goals). Last but not least, the paper identifies the different perspectives used when defining the concept, in order to provide the proper background for understanding "controlling": the information-oriented perspective, the coordination-oriented perspective and the reflection-oriented perspective, and the rationalityoriented perspective.
\end{abstract}

\section{Keywords}

controlling; management; definition; corporate governance; controversies

\section{JEL Classification}

M14; M49

\section{Introduction}

Controlling is an enigmatic concept, which is used both in theory and in practice for a variety of activities. At present, there is no generally accepted definition of this concept, and the vagueness of the term is underlined by Anthony (1965) as follows: "In practice, people with the title of controller have functions that are at one extreme, little more than bookkeeping and, at the other extreme, de facto general management". Behringer (2011) observes that the diversity of ways of understanding controlling becomes obvious if screening the publicly available job announcements. Under the name of "controlling”, employers search for very different tasks, ranging from an accounting-oriented controller to a controller with numerous responsibilities in projects and investments. Preißler argues that each researcher that deals with this topic has his own perceptions on what the meaning of controlling is or should be however, these perceptions differ. The paper has the objective to perform an in-depth analysis of the concept of controlling. The paper is structured as follows. The first section offers an overview of the historical roots of the analyzed concept. Secondly, the author contrasts different definitions of the concept of "controlling", whereas the next section identifies the different perspectives used when defining the concept.

\section{Brief history of the concept "Controlling"}

The tasks of controlling are not fully new. This section presents a concise history of controlling, in accordance with Schultz (2010). The roots of the word "controlling" are Latin. The word appeared in the Middle Ages, from the two Latin words: "contra" (against) and "rotulus" (roll). In the 13th Century, these two words merged into 
"Contrarotulus" (counter-accounting). "Counter-accounting” meant checking of the real stocks of goods and money against the written records. This is a control activity that would nowadays belong to the tasks of auditing. In the European Royal Courts and also in monasteries, this "counter-accounting" was performed by a "Contrarotularius". In the 15th Century, this word turned into the official title of "Controller" at the English Royal Court.

Over the Anglo-Saxon language area, both the function and the title of "Controller" arrived in America. In just two years after the establishment of the United States of America, in the year 1778, the US Congress created the job of "Comptroller", who was supposed to supervise the budget management of the American government and to insure its conformity. About 100 years later appeared the first position of Controller in the private field: in the year 1880, the company "Atchison, Topeka \& Santa Fe Railway System" created the position of controller, whereas the respective person had mostly financial responsibilities.

However, it was only after the economic crisis in the 1920s that controlling established as an important functional area in companies. Following the dramatic company crashes, most big companies in the US set a controller job. Middle and small companies followed. Controlling gained quickly a great significance, so that already in 1931 appeared the first advocacy group called "Controller's Institute of America”. In 1962 this body was renamed as "Financial Executive Institute” (FEI).

In USA, controller tasks were proposed by the Financial Executive Institute, as follows:

- Planning: development of profit plans, distribution plans and investment plans for the company, as well as budgeting systems and planning procedures,

- Reporting and interpretation of data: control through the comparison between plan and reality, analysis and interpretation of deviations, reporting to management and owners, data processing system development, coordination of reporting systems and procedures,

- Assessment and advice: assessment of results, advice to management regarding goals;

- Tax calculation and optimization, including the development of procedures for dealing with fiscal issues;

- External reporting: supervision and coordination of the preparation of compulsory reports to the national authorities,

- Protection of company assets by enforcing proper internal control,

- Continuous research and analysis of economic or political environment.

\section{Definitions of "Controlling”}

Rambusch (2012) identifies two types of “controlling” concepts: concepts oriented towards the goal to obtain results and concepts oriented towards the universal goals of the company.

First of all, in the definitions oriented towards results, the main task of controlling is to coordinate all sub-plans of the company and, in this context, to support the goals related to turnover, costs or profit. Representatives of this approach are Coenenberg and Baum (1992), Hahn (1996), Horvath (2006), Lachint (1992), Reichmann (2006), and Serfling (1992).

Coenenberg and Baum (1992) define controlling through the following tasks: coordination and control of the target goals; supervising the internal and external company processes; keeping the flexibility of the company; dealing with complexity. According to Hahn (1996), controlling has the informational function to support 
result-oriented management. Horvath (2006) gives a similar definition of controlling and describes controlling as a subsystem which supports company management and coordinates the planning, control and supply of information.

On the other hand, Lachint (1992) defines "controlling” as a systematic approach to improve the impact of the company's management and considers controlling a service function for management. This service function uses a modern information and communication technology and comprises concepts, instruments as well as information to support company's management to achieve its financial targets.

Reichmann (2006) describes the main goals of controlling as: support for planning, coordination of subsystems, as well as control of the economic results. Thus, controlling has the role of a management information system.

Serfling (1992) defines controlling as a system of information supply to the management through planning, control, analysis and development of action alternatives to run company operations. This system serves the efficient and effective achievement of profitability goals. Moreover, Serfling (1992) considers that controlling is a management philosophy as well as a communication approach and an instrument of company management.

Second of all, the definitions of "controlling" oriented towards the universal goals of the company are definitely wider. The main task controlling consists in the coordination of the entire sub-plans and managerial subsystems, such as human resources management and company organization. Representatives of this approach in defining controlling are Küpper, Weber and Wöhe.

In brief, Küpper (2008) defines "Controlling” as the "coordination of the management system", whereas the coordination refers to the subsystems: planning, control, information system, organization and human resources management. Küpper (2008) acknowledges that controlling should go beyond profit targeting and should comprise goals related to products, potential, environmental or social aspects.

In a similar mind frame, Weber (2004) defines controlling as a special management function and describes a variety of tasks that serve to an efficient and effective management. On the other hand, Wöhe (2005) considers that controlling is the sum of all measures that support the coordination of the areas management, planning, control, organization, human resources and information, so that the company's goals are achieved in the best way possible.

\section{Perspectives in defining the concept "Controlling"}

Besides a variety of definition, there are also a variety of perspectives in defining "controlling", which are presented in this section. In accordance to the research of Ossadnik et al (2010), there is the information-oriented perspective, the coordinationoriented perspective and the reflection-oriented perspective.

The information-oriented perspective: the main task of controlling is to supply to the company's management information that is relevant for the managerial process. From this perspective, Müller defines controlling as a "central institution of the business infonomics". Following this definition, controlling has the task to determine the informational needs of the company and to prepare and provide the required information, as a solution oriented towards both the problem and the receiver. The information source of controlling is the accounting system, which depending on its design, may be supplemented by other information systems.

The coordination-oriented perspective: on the other hand, the purpose of controlling is to coordinate intra- and inter-systemically the various management subsystems of a company. This perspective is based on the theoretical separation of the company in a performance system, an execution system and a management system, the last being divided into subsystems. Splitting the company into different 
subsystems generates the need for coordination. All execution actions need to be coordinated towards achieving the company goals, whereas the task to formulate company goals and direct the execution system towards these goals belongs to management (the so-called primary coordination). In order for this primary coordination to be possible, it is necessary to connect together the subsystems that build up the management system. This coordination task (the so-called secondary coordination) belongs to controlling.

The reflection-oriented perspective: the view on "controlling" presented by Pietsch and Sherm aims at defining more precisely "controlling" as a management and leadership support function. In this view, controlling as managerial function has the task to serve the "reflection of decisions that were taken in the context of other management functions, and ... [the] reflection of the coordination between these decisions." This managerial function derives the managerial support function of controlling. This function consists in adequately making available to the management an informational overall view.

Last but not least, the rationality-oriented perspective: According to the opinion of Weber and Schäffer (1999), controlling has the task of insuring the rationality of the management. Generally, management has to make a variety of decisions, whereas this decision-making process must take place on the background of bounded rationality (Simon, 1961). The manager is willing to make a rational decision, but due to the limitations of human perception and information processing, he/her is not able to actually make a rational decision. Sanders and Kianty (2006) mention the following human limitations: (1) knowledge limitation: there is no complete information on all situations in the company and on the market; (2) anticipation limitation: managers may not fully anticipate the possible consequences of actions; (3) limitation of opportunities for actions: the management cannot fully comprehend which are the available opportunities for actions.

Even under these limitations, the tendency is to make decisions rationally as possible. Therefore, controlling is the function that was created within the company exactly to perform this task - namely to ensure the rationality of the management as far as possible (although the identified limitations also apply for controlling).

\section{Discussions and conclusions}

Nowadays, management deals more and more with complexity, caused by several factors: economic crises, increased scope and diversity of the own company's activity, dynamics and complexity of the corporate environment, as well as high competitiveness on the market. On this background, there is a stringent need for a superior management support system which can provide the required information and which can reconcile the planning, the control and the information supply for the company's welfare. Such tasks are carried out by controlling.

However, although controlling is needed and already widespread, especially in German-speaking countries, there is no generally accepted definition of controlling. In our opinion, one of the reasons may be the fact that it is an English term, an Anglicism for which no proper word has been found in the local language(s). This leaves room for manoeuvre and keeps the discussions open. The academic literature comprises a diversity of controlling definitions: there are definitions oriented towards results, as well as definitions focused on the universal goals of the company. Additionally, the variety of perspectives (such as the information-oriented perspective, the coordination-oriented perspective, the reflection-oriented perspective, and the rationality-oriented perspective) makes the definition of controlling even more difficult. 
The present paper's contribution consists in the systematization of the most important understandings of the concept of "controlling" in the academic literature. Moreover, by also taking into consideration the history of the concept, the existing definitions and the potential perspectives, the author extracts from the literature a definition of controlling that corresponds to her view and shall be used in future research, namely: "controlling is a system that provides the necessary instruments and pieces of information, so that the management can supervise and coordinate the current business, compare alternative actions and take well-substantiated decisions. “

\section{Acknowledgements}

This work was cofinanced from the European Social Fund through Sectoral Operational Programme Human Resources Development 2007-2013, project number POSDRU/159/1.5/S/142115 „Performance and excellence in doctoral and postdoctoral research in Romanian economics science domain”.

\section{References}

Anthony, R.N. (1965), Planning and control systems: a framework for analysis, Harvard University Press, Boston.

Behringer, S. (2011), Konzerncontrolling, Springer-Verlag Berlin Heidelberg

Coenenberg, A. G., Baum, H. G. (1992), Unternehmenspolitik und Umweltschutz, Universität Augsburg (Germany). Schwerpunkt Wirtschaftspruefung und Controlling.

Horvath, P. (2006), Controlling, 10th Edition, Vahlen, München.

Müller, W. (1974), "Die Koordination von Informationsbedarf und Informationsbeschaffung als zentrale Aufgabe des Controlling”, Zeitschrift für betriebswirtschaftliche Forschung (zfbf), No. 26, p. 683-693.

Ossadnik, W., van Lengerich E.,'Barklage D. (2010), Controlling mittelständischer Unternehmen. Empirischer Status quo und Handlungsempfehlungen, Springer-Verlag Berlin Heidelberg.

Pietsch, G., Scherm, E. (2001), “Die Reflexionsaufgabe im Zentrum des Controlling”, Controlling and Management Review, No. 45, p. 307-313.

Preißner, A. (2002), Profit center managen, Hanser, München.

Rambusch R. (2012), Interne Kundenzufriedenheit mit dem Controllerbereich, Gabler Verlag | Springer Fachmedien, Wiesbaden.

Sanders K., Kianty A. (2006), Organisationstheorien. Eine Einführung, VS, Wiesbaden.

Schultz V. (2010), Basiswissen Controlling. Instrumente für die Praxis, Deutscher Taschenbuch Verlag, München.

Simon H.A. (1961), Administrative behavior, 2nd Edition, Macmillan, New York.

Weber J., Schäffer U. (1999), "Sicherstellung der Rationalität von Führung als Aufgabe des Controlling?”, Betriebswirtschaft 59(6), p. 731-747.

Wöhe G. (2005), Einführung in die allgemeine Betriebswirtschaftslehre, Vahlen, München. 